\title{
Phylogenetic analysis and recombination events in full genome sequences of apple stem grooving virus
}

\author{
H. CHEN, S. CHEN, Y. LI, T. YE, L. HAO, Z. FAN, L. GUO, T. ZHOU*
}

\begin{abstract}
State Key Laboratory for Agro-Biotechnology and Department of Plant Pathology, China Agricultural University,
\end{abstract} Beijing 100193, P. R. China

Received May 7, 2014; accepted November 3, 2014

\begin{abstract}
Summary. - Apple stem grooving virus (ASGV) is one of the most important viral pathogens infecting pome and stone fruit trees worldwide. In this study, with the complete nucleotide sequence of isolate ASGV-T47, which we generated, molecular variation and recombination in ASGV full genomic sequences worldwide were analyzed. ASGV-T47 shared 79.7-97.6\% nucleotide identity with the other isolates worldwide and had the highest identity with an isolate from Japan. Phylogenetic analysis based on whole genome clustered all 16 isolates from around the world into two groups with no correlation to host or geographical origin. Four isolates were detected to be recombinants. Selection pressure estimation indicated that the two codons at positions 1756 and 1798 are under positive selection, while purifying selection is the primary evolutionary dynamics for ASGV.
\end{abstract}

Keywords: capillovirus; full genome sequence; recombination; variation; evolution; selection

\section{Introduction}

Apple stem grooving virus (ASGV) is the type member of the genus Capillovirus in the family Betaflexiviridae (Adams et al., 2012) and has a single-stranded RNA genome consisting of approximately 6,500 nucleotides (nt), with particles of $600-700 \mathrm{~nm}$ in length. The genome contains two overlapping open reading frames (ORFs). ORF1 encodes a polyprotein $(241 \mathrm{kDa})$ containing the replication-associated proteins and a coat protein (CP), while ORF 2 encodes a $36 \mathrm{kDa}$ movement protein (MP) located within the sequence of ORF1, but having a different reading frame (Yoshikawa et al., 1992; Ohira et al., 1995; Hirata et al., 2003). Recent studies revealed that the CP is expressed from a subgenomic RNA (Tatineni et al., 2009a) and it is essential for infection (Komatsu et al., 2012). ASGV has a wide host range including pome fruits, stone

*Corresponding author. E-mail: taozhoucau@cau.edu.cn; phone: +8610-62732771.

Abbreviations: ASGV = apple stem grooving virus; $\mathrm{CP}=$ coat protein; $\mathrm{ORF}(\mathrm{s})=$ open reading frame $(\mathrm{s}) ; \mathrm{SPMMV}=$ sweet potato mild mottle virust fruits, citrus, and lily (Sawamura et al., 1988; Takahashi et al., 1990; Ohira et al., 1994; Adams et al., 2012; Hailstones et al., 2000), and it is one of the most economically important viruses infecting pome and stone fruit trees worldwide (Khan and Dijkstra, 2006). ASGV is transmitted by grafting and no vectors are known (Adams et al., 2012). Associated with latent infections in many commercial apple and pear cultivars (Lister 1970), ASGV dramatically reduces plant growth and productivity (Pleše et al., 1975; Yanase, 1982; Cembali et al., 2003). In China, 33.4-100\% of apple trees were infected by ASGV in different production regions (Liu and Wang, 1989, and our unpublished data).

Abundant genetic variations exist in RNA virus populations owing to the error-prone replication caused by the lack of proofreading activity of RNA-dependent RNA polymerase (RdRp), small genomes, extremely short generation times, and large population sizes (Domingo and Holland, 1997; Drake and Holland, 1999). Moreover, recombination plays an important role in the evolution of RNA viruses. The recombination in RNA viruses can cause a selective advantage over parental viruses in certain instances and act as a major factor in deleterious mutation clearance (Simon and Bujarski 
1994), which could facilitate host adaptation and contribute to RNA virus evolution (Holmes, 2009).

For ASGV and other capilloviruses, there are few reports on analyzing the molecular variation and recombination. A recent study described genomic evolution based on the two variable regions of ASGV genome (Liebenberg et al., 2012), however, there is no genetic analysis, recombination test, or investigation of natural selection based on the whole genome. In this study, to gain insights into the evolutionary mechanism of ASGV, the complete sequence of an isolate ASGV-T47 was first determined, and it was compared with 15 other isolates worldwide to investigate their genetic variation, recombination and phylogenetic relationships on whole genome level.

\section{Materials and Methods}

Virus and plant material. The isolate ASGV-T47 was propagated on apple in vitro plantlets, which were generated from one bud on an ASGV-infected apple tree (Malus domestica cv. Fuji) growing at a garden in Changping district, Beijing, China, in a growth chamber at a temperature of $25 \pm 1^{\circ} \mathrm{C}$ under a 16 -hr light/8-hr dark photoperiod with a light intensity of $3600 \mathrm{Lx}$ by cool-white fluorescent tubes.

RNA isolation, reverse transcription PCR, cloning and sequencing. Total RNA was extracted from leaves of apple in vitro plantlets by an EASYspin plant total RNA extraction kit (Biomed, China) according to the manufacturer's instructions. First-strand cDNA was synthesized using Superscript III reverse transcriptase (Invitrogen, USA) with a random primers. Polymerase chain reaction (PCR) was performed with high-fidelity Golden Taq DNA polymerase (FunGenome, China) using specific primers (Table 1) designed according to the reference ASGV genomic sequence (NC_001749). To amplify the 3 '-terminal region, a modified oligo $\mathrm{d}(\mathrm{T})$ primer $\mathrm{R} 4$ and an ASGV-specific primer F4 were used (Table 1). The 5'terminal region was determined using the classic 5 '-RACE method (Scotto-Lavino et al., 2006). PCR products were purified using EasyPure Quick gel extraction kit (TIANGEN, China) according to the manufacturer's instructions. The purified PCR products were then ligated to vector pMD18-T (TaKaRa, China) and transformed into $E$. coli strain DH5a competent cells. Consistent sequences were obtained from at least three independent positive clones.

Sequence identity and phylogenetic analysis. The full-length genome sequence of ASGV-T47 was assembled using the SeqMan program in the software Lasergene DNASTAR (DNASTAR Inc., USA). Identities at the nt and putative amino acid (aa) levels between sequences were evaluated with the MegAlign program in DNASTAR (http://www.dnastar.com). Phylogenetic analysis was performed with the neighbor-joining algorithm using the Maximum composite likelihood method with 1,000 bootstrap replicates as implemented in the Molecular Evolutionary Genetics Analysis tool (MEGA v.5.0) (Tamura et al., 2011).
Recombination analysis and selection pressure analysis. Recombination was tested by seven different programs, RDP (Martin and Rybicki, 2000), GENECONV (Padidam et al., 1999), BootScan (Martin et al., 2005), MaxChi (Smith, 1992), Chimaera (Posada and Crandall, 2001), SiScan (Gibbs et al., 2000), and 3Seq (Boni et al., 2007) within the RDP3 software package (Martin et al., 2010). $P$-value was estimated according to the default parameters, except for the options of linear sequence and of disentangling overlapping signals (Cordin et al., 2012; Li et al., 2013a,b). Natural selection was investigated by the $\mathrm{dN}$ (the rate of non-synonymous substitutions per non-synonymous sites) to dS (the rate of synonymous substitutions per synonymous sites) ratio ( $\omega$ ) using the Pamilo-Bianchi-Li method implemented in MEGA5 (Pamilo and Bianchi 1993; Tamura et al., 2011). For each codon, the value of $\omega$ was estimated to identify selection using SLAC, FEL, and IFEL within the HYPHY software package on the Datamonkey server (www.datamonkey. org) (Pond and Frost, 2005) by setting the significance levels at $P=0.05$ (Cordin et al., 2012)

\section{Results}

The full genome sequence of isolate ASGV-T47 was assembled from 5 fragments including $3^{\prime}$-terminal and $5^{\prime}$ terminal regions (Table 1), and was assigned to GenBank Acc. No. KF434636. It consists of 6,496 nt, excluding the poly(A) tail, and contains three ORFs, encoding a 241 $\mathrm{kDa}$ protein, which is involved in replication, a $36 \mathrm{kDa}$ MP (ORF2), and a $27 \mathrm{kDa}$ CP (ORF3), as is characteristic for ASGV. To compare the identity of ASGV-T47 genome sequence to other isolates from around the world, totally 15 isolates fully sequenced worldwide were retrieved from GenBank (Table 2). ASGV-T47 shared a 79.7-97.6\% identity with the other 15 isolates, and had the highest identity to a Japanese isolate (NC_0011749) not only for the whole genome sequence $(97.6 \%)$ but also for each ORF in both nt (97.2-98.5\%) and aa (96.9-99.6\%) sequence (Table 2). Among the 5 isolates from China, ASGV-T47 has the highest identity to a citrus isolate (KC588948) on whole genome sequence (90.9\%), ORF1 (90.7\%), ORF2 (91.5\%) and ORF3 (92.2\%) on nt level, while on aa level, ORF1 of ASGV-T47 has the highest identity (93.9\%) with a citrus isolate (KC588948), while ORF2 and ORF3 have the highest identities (95.0\% and $97.1 \%$, respectively) with sand pear isolate (JN701424) (Table 2).

All 16 isolates shared $78.8 \%$ to $98.5 \%$ identities with each other (Table 3). For particular ORFs, the identities at the nt and aa levels between the 16 isolates were $79.2-97.5 \%$ (nt) and 85.6-98.2\% (aa ORF1), 84.2-97.2\% (nt) and 92.2-96.9\% (aa ORF2), and 89.1-98.5\% (nt) and 94.1-99.6\% (aa ORF3) (data not shown), respectively, indicating that the $\mathrm{CP}$, as reported previously (Magome et al., 1997), is the most conserved. Moreover, the alignment of the ORF1 aa sequences 
Table 1. Primers used to amplify the full-length genome of ASGV

\begin{tabular}{|c|c|c|c|}
\hline Primers & Sequences $\left(5^{\prime}-3^{\prime}\right)$ & Annealing temperature & Nucleotide positions \\
\hline F1 & ACCTTAGAAGTGACCAACC & \multirow{2}{*}{$54^{\circ} \mathrm{C}$} & \multirow{2}{*}{$138-3633$} \\
\hline $\mathrm{R} 1$ & GAACACCTGCCCAGAAAGTAAC & & \\
\hline $\mathrm{F} 2$ & GATCCGACGCTTGCGGAGAT & \multirow{2}{*}{$62^{\circ} \mathrm{C}$} & \multirow{2}{*}{$3438-4965$} \\
\hline $\mathrm{R} 2$ & AGGCCGTCACCAGATCGAGA & & \\
\hline F3 & GGGTCCAAATGGCTATCGT & \multirow{2}{*}{$55^{\circ} \mathrm{C}$} & \multirow{2}{*}{$4779-5874$} \\
\hline $\mathrm{R} 3$ & CGGGAAACTGGGTCTTGTCAG & & \\
\hline $\mathrm{F} 4$ & AAGAGAGGATTTAGGTCCCTC & \multirow{2}{*}{$56^{\circ} \mathrm{C}$} & \multirow{2}{*}{$5592-3$ 'end } \\
\hline $\mathrm{R} 4$ & CAGGATCCAAGCTTTTTTTTTTTTTTTTTT & & \\
\hline$Q_{\text {total }}$ & CCAGTGAGCAGAGTGACGAGGACTCGAGCTCAAGCTTTTTTTTTTTTTTTTT & \multirow{3}{*}{$58^{\circ} \mathrm{C}$} & \multirow{3}{*}{ 5'end-240 } \\
\hline $\mathrm{Q}_{\text {outer }}$ & CCAGTGAGCAGAGTGACG & & \\
\hline GSP1 & GGATACTGGATGGGAGTGTGA & & \\
\hline $\mathrm{Q}_{\text {inner }}$ & GAGGACTCGAGCTCAAGC & \multirow[t]{2}{*}{$56^{\circ} \mathrm{C}$} & \multirow{2}{*}{ 5'end-201 } \\
\hline GSP2 & GTGTCAGACCATGTTTGGTC & & \\
\hline
\end{tabular}

GSP1: gene-specific primer 1; GSP2: gene-specific primer 2.

Table 2. Percentage of nucleotide and predicted amino acid sequence identities of ASGV-T47 to other complete ASGV genomes available in GenBank

\begin{tabular}{|c|c|c|c|c|c|c|c|c|c|}
\hline \multirow{2}{*}{ GenBank No. } & \multirow{2}{*}{ Host } & \multirow{2}{*}{$\begin{array}{c}\text { Location of virus } \\
\text { isolation (year) }\end{array}$} & \multirow{2}{*}{$\begin{array}{c}\text { Genome } \\
\text { identity (\%) }\end{array}$} & \multicolumn{3}{|c|}{ Nucleotide identity (\%) } & \multicolumn{3}{|c|}{ Amimo acid identity (\%) } \\
\hline & & & & ORF1 & ORF2 & $\mathrm{CP}$ & ORF1 & ORF2 & $\mathrm{CP}$ \\
\hline AB004063 & Lily & Japan (1997) & 82.9 & 82.5 & 85.4 & 92.2 & 88.0 & 94.4 & 98.3 \\
\hline AY596172 & Pear & South Korea (2004) & 79.7 & 79.2 & 84.2 & 89.9 & 85.6 & 92.2 & 95.0 \\
\hline FJ355920 & Citrus & Taiwan (2004) & 81.7 & 81.2 & 85.5 & 89.5 & 87.9 & 94.4 & 96.6 \\
\hline JX416228 & Citrus & Taiwan (2012) & 81.8 & 81.3 & 85.0 & 89.6 & 87.7 & 94.4 & 94.1 \\
\hline AY646511 & Kumquat & Taiwan (2004) & 81.8 & 81.4 & 85.7 & 89.8 & 87.8 & 94.1 & 95.4 \\
\hline D16681 & Lily & Japan (1993) & 82.9 & 82.5 & 84.9 & 91.9 & 88.4 & 94.4 & 98.3 \\
\hline EU553489 & Meyer lemon & USA (2008) & 81.8 & 81.5 & 84.6 & 90.6 & 87.1 & 95.0 & 94.5 \\
\hline JQ765412 & Citrus & China (2011) & 81.6 & 81.2 & 85.0 & 89.6 & 87.7 & 93.5 & 95.0 \\
\hline JN701424 & Sand pear & China (2009) & 87.1 & 86.8 & 86.0 & 91.7 & 90.5 & 95.0 & 97.1 \\
\hline JQ308181 & Apple & China (2011) & 86.4 & 86.1 & 86.2 & 91.3 & 90.7 & 93.5 & 96.6 \\
\hline JX080201 & Apple & Germany (2009) & 82.5 & 82.1 & 85.0 & 91.5 & 88.0 & 95.3 & 97.9 \\
\hline NC_001749a & Apple & Japan (1993) & 97.6 & 97.5 & 97.2 & 98.5 & 98.2 & 96.9 & 99.6 \\
\hline HE978837 & Apple & India (2012) & 81.3 & 80.8 & 84.2 & 90.9 & 85.1 & 93.1 & 97.5 \\
\hline KC588947 & Citrus & China (2013) & 81.2 & 80.8 & 84.8 & 89.1 & 87.2 & 93.4 & 94.5 \\
\hline KC588948 & Citrus & China (2013) & 90.9 & 90.7 & 91.5 & 92.2 & 93.9 & 94.7 & 96.2 \\
\hline
\end{tabular}

aJapanese isolate (NC_001749) which shares the highest identity to ASGV-T47.

of the 16 ASGV isolates revealed two highly variable regions, one from aa 532 to 570 and another from aa 1,583 to 1,868 , which were the same as in previous reports (Tatineni et al., 2009b; Liebenberg et al., 2012).

To investigate the genetic relationship of ASGV isolates worldwide based on whole genome sequences, a phylogenetic analysis was performed with the neighbor-joining algorithm (Fig. 1). It indicated that the ASGV clusters had no correlation to host or geographical origins.

Though two recombinants were reported based on the $c p$ genes alone (Negi et al., 2010), the profile of recombination on complete ASGV genome sequences remains unknown. In this study, the 16 full genomic sequences worldwide were processed and tested for recombination. Four recombinants were detected to be "clear" recombinants by five different methods (Table 4). The major parent, minor parent, beginning breakpoint, ending breakpoint, programs detecting the event and the corresponding $P$-value for all recombinants are listed in Table 4. Three recombinants, two lily isolates from Japan (AB004063 and D16681) and one pear isolate from China (JN701424), originated from the same parents; their major parent was an apple isolate from Germany (JX080201) and their minor parent was a pear isolate from South Korea (AY596172). The two recombinants, AB004063 and D16681, shared the beginning and ending breakpoints located at nt 5094 and nt 5557, while recombinant JN701424 had its beginning and 
ending breakpoints located at nt 4888 and nt 5519. The fourth recombinant event was observed between two citrus isolates, JX416228 from Taiwan as the major parent, and JQ765412 from China as the minor parent, leading to the recombinant citrus isolate (FJ355920) from Taiwan. Given the fact that ASGV can be transmitted by grafting with no known vectors (Adams et al., 2012), the recombination between isolates from different host species and different countries was likely to be the result of long-distance transportation of infected propagation materials between countries and multiple grafting on a tree.

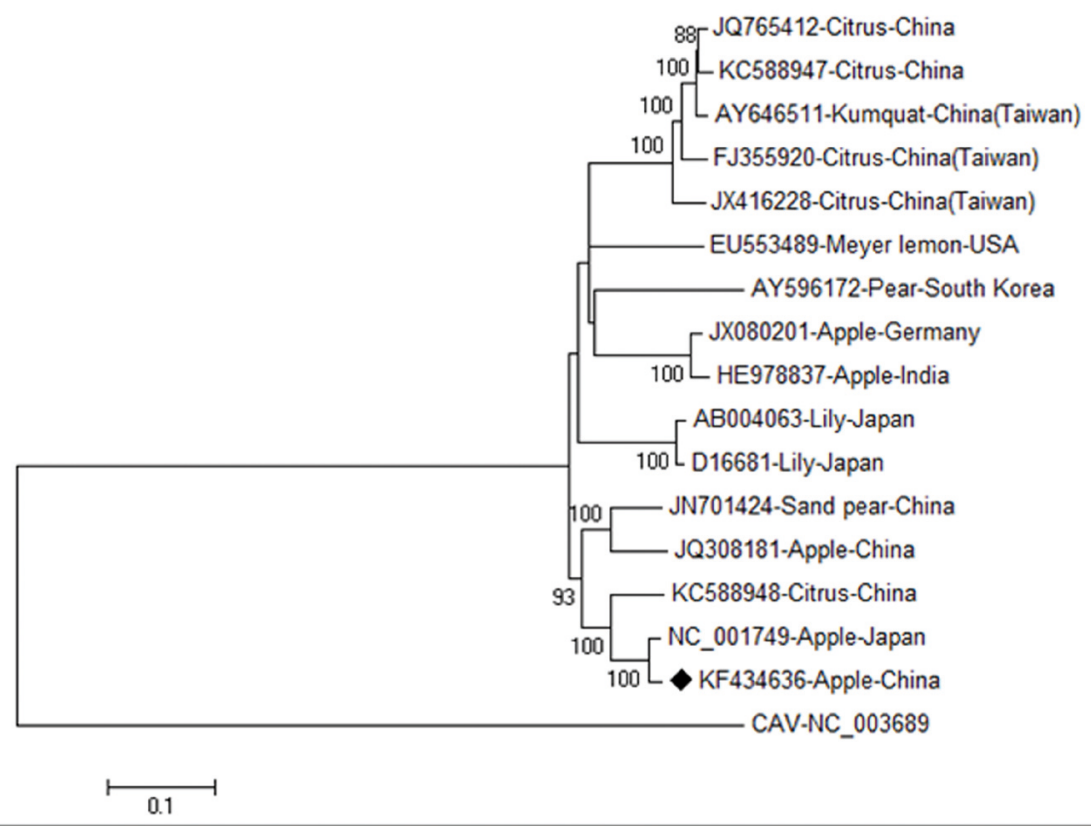

Fig. 1

Neighbor-joining tree depicting the phylogenetic relationships based on whole genomic sequences of ASGV isolates available in GenBank

The bootstrapping replicates $=1,000$. Only branches with bootstrap values of $\geq 70 \%$ are shown. Cherry virus A (CVA) was used as the outgroup. The scale bar represents the genetic distance (substitutions per nucleotide). ASGV-T47 is marked with a black diamond.

Table 3. Percentage of nucleotide sequence identities of 16 full-length genomes of ASGV worldwide

\begin{tabular}{|c|c|c|c|c|c|c|c|c|c|c|c|c|c|c|c|c|}
\hline & $\begin{array}{c}\text { NC00 } \\
1749\end{array}$ & $\begin{array}{c}\text { KC58 } \\
8948\end{array}$ & $\begin{array}{c}\text { KC58 } \\
8947\end{array}$ & $\begin{array}{l}\text { JX41 } \\
6228\end{array}$ & $\begin{array}{l}\text { JX08 } \\
0201\end{array}$ & $\begin{array}{c}\text { JQ76 } \\
5412\end{array}$ & $\begin{array}{c}\text { JQ30 } \\
8181\end{array}$ & $\begin{array}{r}\text { JN70 } \\
1424\end{array}$ & $\begin{array}{l}\text { HE07 } \\
8837\end{array}$ & $\begin{array}{l}\text { FJ35 } \\
5920\end{array}$ & $\begin{array}{c}\text { EU55 } \\
3489\end{array}$ & $\begin{array}{l}\mathrm{D} 16 \\
681\end{array}$ & $\begin{array}{c}\text { AY64 } \\
6511\end{array}$ & $\begin{array}{c}\text { AY59 } \\
6172\end{array}$ & $\begin{array}{c}\text { AB00 } \\
4063\end{array}$ & $\begin{array}{r}\text { KF43 } \\
4636\end{array}$ \\
\hline KF434636 & 97.6 & 90.9 & 81.2 & 81.8 & 82.5 & 81.6 & 86.4 & 87.1 & 81.6 & 81.7 & 81.8 & 82.9 & 81.8 & 79.7 & 82.9 & 100 \\
\hline AB004063 & 83.0 & 83.3 & 80.9 & 81.6 & 81.6 & 81.2 & 83.0 & 84.1 & 80.9 & 81.3 & 81.3 & 98.5 & 81.3 & 80.4 & 100 & \\
\hline AY596172 & 79.8 & 79.9 & 78.8 & 79.0 & 80.1 & 79.0 & 80.0 & 79.8 & 79.9 & 79.0 & 79.4 & 80.5 & 79.0 & 100 & & \\
\hline AY646511 & 81.9 & 82.4 & 97.6 & 94.0 & 81.8 & 98.0 & 81.2 & 81.6 & 81.6 & 95.1 & 81.9 & 81.4 & 100 & & & \\
\hline D16681 & 83.0 & 83.5 & 80.9 & 81.6 & 81.7 & 81.2 & 83.1 & 84.1 & 80.9 & 81.3 & 81.4 & 100 & & & & \\
\hline EU553489 & 81.7 & 82.1 & 81.4 & 81.8 & 81.8 & 81.7 & 81.5 & 81.1 & 81.5 & 81.9 & 100 & & & & & \\
\hline FJ355920 & 81.7 & 82.0 & 95.2 & 93.9 & 82.1 & 95.4 & 81.4 & 81.5 & 81.7 & 100 & & & & & & \\
\hline HE078837 & 81.8 & 81.5 & 81.5 & 81.6 & 97.3 & 81.6 & 80.9 & 81.2 & 100 & & & & & & & \\
\hline JN701424 & 87.1 & 86.5 & 81.1 & 82.0 & 81.9 & 81.7 & 90.5 & 100 & & & & & & & & \\
\hline JQ308181 & 86.3 & 85.8 & 80.9 & 81.6 & 81.5 & 81.4 & 100 & & & & & & & & & \\
\hline JQ765412 & 81.7 & 82.3 & 98.0 & 94.1 & 81.9 & 100 & & & & & & & & & & \\
\hline JX080201 & 82.7 & 82.1 & 81.8 & 81.9 & 100 & & & & & & & & & & & \\
\hline JX416228 & 81.7 & 82.1 & 93.7 & 100 & & & & & & & & & & & & \\
\hline KC588947 & 81.3 & 81.9 & 100 & & & & & & & & & & & & & \\
\hline KC588948 & 91.1 & 100 & & & & & & & & & & & & & & \\
\hline NC001749 & 100 & & & & & & & & & & & & & & & \\
\hline
\end{tabular}

This highlighted isolate (KF434636) is ASGV-T47. 
Table 4. Recombination events detected in ASGV isolates worldwide

\begin{tabular}{|c|c|c|c|c|}
\hline $\begin{array}{l}\text { Recombinant } \\
\text { (origin) }\end{array}$ & $\begin{array}{l}\text { AB004063 } \\
\text { (Lily, Japan) }\end{array}$ & $\begin{array}{l}\text { D16681 } \\
\text { (Lily, Japan) }\end{array}$ & $\begin{array}{l}\text { JN701424 } \\
\text { (Sand pear, China) }\end{array}$ & $\begin{array}{l}\text { FJ355920 } \\
\text { (Citrus, Taiwan) }\end{array}$ \\
\hline $\begin{array}{l}\text { Major parent } \\
\text { (origin) }\end{array}$ & $\begin{array}{l}\text { JX080201 } \\
\text { (Apple, Germany) }\end{array}$ & $\begin{array}{l}\text { JX080201 } \\
\text { (Apple,Germany) }\end{array}$ & $\begin{array}{l}\text { JX080201 } \\
\text { (Apple,Germany) }\end{array}$ & $\begin{array}{l}\text { JX416228 } \\
\text { (Citrus, China) }\end{array}$ \\
\hline $\begin{array}{l}\text { Minor parent } \\
\text { (origin) }\end{array}$ & $\begin{array}{l}\text { AY596172a } \\
\text { (Pear, South Korea) }\end{array}$ & $\begin{array}{l}\text { AY596172a } \\
\text { (Pear, South Korea) }\end{array}$ & $\begin{array}{l}\text { AY596172a } \\
\text { (Pear, South Korea) }\end{array}$ & $\begin{array}{l}\text { JQ765412 } \\
\text { (Citrus, China) }\end{array}$ \\
\hline \multicolumn{5}{|c|}{ P-values determined using seven different programs } \\
\hline RDP & $3.602 \times 10^{-5}$ & $3.602 \times 10^{-5}$ & $3.602 \times 10^{-5}$ & ND \\
\hline GENECONV & ND & ND & ND & $7.485 \times 10^{-4}$ \\
\hline BootScan & $1.764 \times 10^{-5}$ & $1.764 \times 10^{-5}$ & $1.764 \times 10^{-5}$ & $9.653 \times 10^{-5}$ \\
\hline MaxChi & $2.357 \times 10^{-5}$ & $2.357 \times 10^{-5}$ & $2.357 \times 10^{-5}$ & $5.431 \times 10^{-3}$ \\
\hline Chimaera & $4.448 \times 10^{-3}$ & $4.448 \times 10^{-3}$ & $4.448 \times 10^{-3}$ & $4.405 \times 10^{-2}$ \\
\hline SiScan & $7.615 \times 10^{-6}$ & $7.615 \times 10^{-6}$ & $7.615 \times 10^{-6}$ & $1.082 \times 10^{-2}$ \\
\hline 3 Seq & ND & ND & ND & ND \\
\hline Beginning breakpoint (nt) & 5094 & 5094 & $4888^{\mathrm{b}}$ & 4417 \\
\hline Ending breakpoint (nt) & 5557 & 5557 & 5519 & 4909 \\
\hline
\end{tabular}

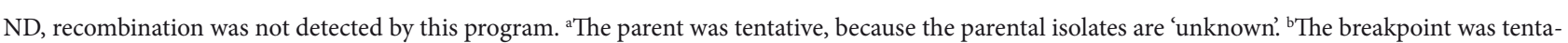
tive, because the breakpoint is 'unknown'.

Finally, natural selection was examined by estimating the selection pressure on ORF1 and each of its codons using the $\mathrm{dN}$ to $\mathrm{dS}$ ratio $(\omega)$. ORF1 was chosen for the analysis, because it covers almost the entire ASGV genome and encodes proteins for replication and encapsidation. The values of $\mathrm{dN}$ and dS for ORF1 were separately estimated to be 0.1738 and 0.2825 , respectively. Consequently, the $\mathrm{dN} / \mathrm{dS}$ ratio was 0.615 , indicating predominant purifying selection on ORF1. For each codon of ORF1, the value of $\omega$ was estimated to identify selection using SLAC, FEL, and IFEL within the HYPHY software package on the Datamonkey server (www.datamonkey.org) (Pond and Frost, 2005). All three methods concluded that the codons at positions 1756 and 1798 were under positive selection (Table 5), while the other codons were under purifying selection or neutral evolution (data not shown).

\section{Discussion}

In this study, with the newly determined full genome sequence of an isolate, ASGV-T47, from China, two phylogenetic groups and four recombinants were detected among ASGV isolates worldwide. To our knowledge, this is the first analysis of recombination based on complete sequences of ASGV isolates. Though no recombination hotspot was found, recombination events play an important role in ASGV evolution as reported recombination in cp gene (Negi et al., 2010). Moreover, recombination might be common in members of Betaflexiviridae as detected in a few reports (Singh et al., 2007, 2008, 2012; Komorowska et al., 2011; Singh et al., 2012; Dhir et al., 2013; Pramesh and Baranwal, 2013; Alabi et al., 2014;
Table 5. The positive selection estimation results for ASGV ORF1 by three methods: SLAC, FEL, and IFEL

\begin{tabular}{ccccccccc}
\hline \multirow{2}{*}{ Codon } & \multicolumn{2}{c}{ SLAC } & & \multicolumn{2}{c}{ FEL } & & \multicolumn{2}{c}{ IFEL } \\
\cline { 2 - 3 } \cline { 7 - 8 } \cline { 7 - 8 } & $\mathrm{dN}^{\mathrm{a}} / \mathrm{dS}^{\mathrm{b}}$ & P-value & & dN/dS & P-value & & dN/dS & P-value \\
\hline 1756 & 3.982 & 0.043 & & 1.523 & 0.004 & & 1.803 & 0.011 \\
1798 & 4.371 & 0.024 & & 1.870 & 0.003 & & 1.137 & 0.041 \\
\hline
\end{tabular}

${ }^{\mathrm{a}} \mathrm{dN}$, the rate of non-synonymous substitutions per non-synonymous sites. ${ }^{b} \mathrm{dS}$, the rate of synonymous substitutions per synonymous site.

Chen et al., 2014). As no vector is known for ASGV and it can be transmitted by grafting, recombinant events among isolates from different host species and countries, and phylogenetic clusters with no correlation to host or geographical origins are likely to be the result of vegetative propagation and exchanges of propagation materials between countries. At the same time, recombinant events could benefit the survival of ASGV between host species, as recombination contributes to the RNA virus' genetic diversity and ability to adapt to changing environments, including new hosts (Holmes, 2009).

On whole genome, ASGV-T47 has the highest identity (97.6\%) with an isolate (NC_0011749) from Japan and both clustered into the same sub-clade in the phylogenetic tree (Fig. 1), while among all 5 isolates from China, ASGV-T47 shares the highest identity (only 90.9\%) with KC588948. Conclusively, though ASGV-T47 was cloned in China, it might have come from Japan by the transport of vegetative propagation material.

Though previous reports revealed the evolution of ASGV genomic RNA (Liebenberg et al., 2012), our result for the 
first time identified the two codons, at positions 1756 and 1798, under positive selection. Similar results were observed for the $c p$ genes of apple stem pitting virus (Komorowska et al., 2011), grapevine rupestris stem pitting-associated virus (Alabi et al., 2010), sweet potato mild mottle virus (SPMMV) (Tugume et al., 2010), and the P1 proteinase of SPMMV (Tugume et al., 2010), where several codons were under positive selection whereas purifying selection acted on the other sites. Purifying selection could occur by functional constraints during the virus life cycle when interacting with hosts (Schneider and Roossinck, 2000; French and Stenger, 2003), and it is the main evolutionary force (García-Arenal et al., 2001). Further studies will be conducted to test whether the two codons are involved in reactions with host factors.

Acknowledgements. This research was supported by the National High Technology Research and Development Program (863) of China (2012AA101501), the Earmarked Fund for Modern Agro-industry Technology Research System (CARS-28), the Special Fund for Agro-scientific Research in the Public Interest (No. 201203076-02) administered by the Chinese Ministry of Agriculture, and the Program for Changjiang Scholars and Innovative Research Team in University (IRT1042).

\section{References}

Adams MJ, Candresse T, Hammond J, Kreuze JF, Martelli GP, Namba S, Pearson MN, Ryu KH, Saldarelli P, Yoshikawa N (2012): Family Betaflexiviridae. In King AMQ, Adams MJ, Carstens EB, Lefkowitz EJ (Eds): Virus Taxonomy: Ninth Report of the International Committee on Taxonomy of Viruses. Elsevier Academic Press, Amsterdam, pp. 920-941.

Alabi OJ, Martin RR, Naidu RA (2010): Sequence diversity, population genetics and potential recombination events in Grapevine rupestris stem pitting-associated virus in Pacific North-West vineyards. J. Gen. Virol. 91, 265-276. http://dx.doi.org/10.1099/vir.0.014423-0

Alabi OJ, Rwahnih MA, TA Mekuria TA, Naidu RA (2014): Genetic diversity of Grapevine virus A in Washington and California vineyards. Phytopathology 104, 548-560. http:// dx.doi.org/10.1094/PHYTO-06-13-0179-R

Boni MF, Posada D, Feldman MW (2007): An exact nonparametric method for inferring mosaic structure in sequence triplets. Genetics 176, 1035-1047. http://dx.doi.org/10.1534/ genetics.106.068874

Cembali T, Folwell RJ, Wandschneider P, Eastwell KC, Howell WE (2003): Economic implications of a virus prevention program in deciduous tree fruits in the US. Crop. Prot. 22, 1149-1156. http://dx.doi.org/10.1016/S0261-2194(03)00156-X

Chen SY, Zhou Y, Ye T, Hao L, Guo LY, Fan ZF, Li SF, Zhou T (2014): Genetic variation analysis of Apple chlorotic leaf spot virus coat protein reveals a new phylogenetic type and two recombinants in China. Arch. Virol. 159, 1431-1438. http://dx.doi.org/10.1007/s00705-013-1927-9
Cordin O, Hahn D, Beggs JD (2012): Structure, function and regulation of spliceosomal RNA helicases. Curr. Opin. Cell. Biol. 24, 431-438

Dhir S, Zaidi AA, Hallan V (2013): Molecular characterization and recombination analysis of the complete genome of Apple chlorotic leaf spot virus. J. Phytopathol. 161,704-712. http://dx.doi.org/10.1111/jph.12121

Domingo E, Holland J (1997): RNA virus mutations and fitness for survival. Annu. Rev. Microbiol. 51, 151-178. http:// dx.doi.org/10.1146/annurev.micro.51.1.151

Drake JW, Holland JJ (1999): Mutation rates among RNA viruses. Proc. Natl. Acad. Sci. USA 96, 13910-13913. http://dx.doi. org/10.1073/pnas.96.24.13910

French R, Stenger DC (2003): Evolution of Wheat streak mosaic virus: Dynamics of population growth within plants may explain limited variation. Annu. Rev. Phytopathol. 41, 199-214. http://dx.doi.org/10.1146/annurev. phyto.41.052002.095559

García-Arenal F, Fraile A, Malpica JM (2001): Variability and genetic structure of plant virus populations. Annu. Rev. Phytopathol. 39, 157-186. http://dx.doi.org/10.1146/annurev.phyto.39.1.157

Gibbs MJ, Armstrong JS, Gibbs AJ (2000): Sister-scanning: a Monte Carlo procedure for assessing signals in recombinant sequences. Bioinformatics 16, 573-582. http://dx.doi. org/10.1093/bioinformatics/16.7.573

Hailstones D, Bryant K, Broadbent P, Zhou C (2000): Detection of Citrus tatter leaf virus with reverse transcriptionpolymerase chain reaction (RT-PCR). Aust. Plant Pathol. 29, 240-248. http://dx.doi.org/10.1071/AP00046

Hirata H, Lu X, Yamaji Y, Kagiwada S, Ugaki M, Namba S (2003): A single silent substitution in the genome of Apple stem grooving virus causes symptom attenuation. J. Gen. Virol. 84, 2579-2583. http://dx.doi.org/10.1099/vir.0.19179-0

Holmes EC (2009): The evolutionary genetics of emerging viruses. Annu. Rev. Ecol. Evol. Syst. 40, 353-372. http://dx.doi. org/10.1146/annurev.ecolsys.110308.120248

Khan JA, Dijkstra J (2006): Handbook of plant virology. Food Products Press. New York, London, pp. 452.

Komatsu K, Hirata H, Fukagawa T, Yamaji Y, Okano Y, Ishikawa K, Adachi T, Maejima K, Li YQ, Liu RY, Zhou T, Fan ZF (2013a): Genetic diversity and population structure of Sugarcane mosaic virus. Virus Res. 171, 242-246. http:// dx.doi.org/10.1016/j.virusres.2012.10.024

Komorowska B, Siedlecki P, Kaczanowski S, Hasiów-Jaroszewska B, Malinowski T (2011): Sequence diversity and potential recombination events in the coat protein gene of Apple stem pitting virus. Virus Res. 158, 263-267. http://dx.doi. org/10.1016/j.virusres.2011.03.003

Li YQ, Xia ZH, Peng J, Zhou T, Fan ZF (2013b): Evidence of recombination and genetic diversity in Southern rice black-streaked dwarf virus. Arch. Virol. 158, 2147-2151. http://dx.doi.org/10.1007/s00705-013-1696-5

Liebenberg A, Moury B, Sabath N, Hell R, Kappis A, Jarausch W, Wetzel T (2012): Molecular evolution of the genomic RNA of Apple stem grooving capillovirus. J. Mol. Evol. 75, 92-101. http://dx.doi.org/10.1007/s00239-012$\underline{9518-\mathrm{Z}}$ 
Lister R (1970): Apple stem grooving virus. CMI/AAB Descriptions of Plant Viruses, pp. 31.

Liu FC, Wang HY (1989): On latent viruses of apple in China II: Indexing of latent viruses in apple scion varieties and dwarf rootstocks. Acta Phytopathol. Sin. 19, 93-197 (in Chinese).

Magome H, Yoshikawa N, Takahashi T, Ito T, Miyakawa T (1997): Molecular variability of the genomes of capilloviruses from apple, Japanese pear, European pear, and citrus trees. Phytopathology 87, 389-396. http://dx.doi.org/10.1094/ PHYTO.1997.87.4.389

Martin D, Posada D, Crandall K, Williamson C (2005): A modified bootscan algorithm for automated identification of recombinant sequences and recombination breakpoints. AIDS Res. Hum. Retrovir. 21, 98-102. http://dx.doi. org/10.1089/aid.2005.21.98

Martin D, Rybicki E (2000): RDP: detection of recombination amongst aligned sequences. Bioinformatics 16, 562-563. http://dx.doi.org/10.1093/bioinformatics/16.6.562

Martin DP, Lemey P, Lott M, Moulton V, Posada D, Lefeuvre P (2010): RDP3: a flexible and fast computer program for analyzing recombination. Bioinformatics 26, 2462-2463. http://dx.doi.org/10.1093/bioinformatics/btq467

Negi A, Rana T, Kumar Y, Ram R, Hallan V, Zaidi AA (2010): Analysis of the coat protein gene of Indian strain of Apple stem grooving virus. J. Plant. Biochem. Biotechnol. 19, 91-94. http://dx.doi.org/10.1007/BF03323442

Ohira K, Ito T, Kawai A, Namba S, Kusumi T, Tsuchizaki T (1994): Nucleotide sequence of the 3'-terminal region of Citrus tatter leaf virus RNA. Virus Genes 8, 169-172. http:// dx.doi.org/10.1007/BF01703075

Ohira K, Namba S, Rozanov M, Kusumi T, Tsuchizaki T (1995): Complete sequence of an infectious full-length cDNA clone of Citrus tatter leaf capillovirus: comparative sequence analysis of capillovirus genomes. J. Gen. Virol. 76, 2305-2309. http://dx.doi.org/10.1099/0022-1317$\underline{76-9-2305}$

Padidam M, Sawyer S, Fauquet CM (1999): Possible emergence of new geminiviruses by frequent recombination. Virology 265, 218-225. http://dx.doi.org/10.1006/viro.1999.0056

Pamilo P, Bianchi NO (1993): Evolution of the Zfx and Zfy genes: rates and interdependence between the genes. Mol. Biol. Evol. 10, 271-281.

Pleše N, Hoxha E, Miličić D (1975): Pathological anatomy of trees affected with Apple stem grooving virus. J. Phytopathol. 82, 315-325. http://dx.doi.org/10.1111/j.1439-0434.1975. tb03497.x

Pond SLK, Frost SD (2005): Datamonkey: rapid detection of selective pressure on individual sites of codon alignments. Bioinformatics 21, 2531-2533. http://dx.doi.org/10.1093/ bioinformatics/bti320

Posada D, Crandall KA (2001): Evaluation of methods for detecting recombination from DNA sequences: computer simulations. Proc. Natl. Acad. Sci. USA 98, 13757-13762. http:// dx.doi.org/10.1073/pnas.241370698

Pramesh D, Baranwal VK (2013): Molecular characterization of coat protein gene of Garlic common latent virus isolates from India: an evidence for distinct phylogeny and recombina- tion. Virus Genes 47, 189-193. http://dx.doi.org/10.1007/ s11262-013-0909-Z

Sawamura K, Yamashita K, Arai M (1988): An apple stem grooving virus strain isolated from European pear (Pyrus communis). Bull. Fac. Agric. Hirosaki. Univ. 50, 22-26.

Schneider WL, Roossinck MJ (2000): Evolutionarily related sindbislike plant viruses maintain different levels of population diversity in a common host. J. Virol. 74, 3130-3134. http:// dx.doi.org/10.1128/JVI.74.7.3130-3134.2000

Scotto-Lavino E, Du G, Frohman MA (2006): 5 ' end cDNA amplification using classic RACE. Nat. Protoc. 1, 2555-2562. http://dx.doi.org/10.1038/nprot.2006.480

Simon A, Bujarski J (1994): RNA-RNA recombination and evolution in virus-infected plants. Annu. Rev. Phytopathol. 32, 337-362. http://dx.doi.org/10.1146/annurev. py.32.090194.002005

Singh AK, Mahinghara BK, Hallan V, Ram R, Zaidi AA (2008): Recombination and phylogeographical analysis of Lily symptomless virus. Virus Genes 36, 421-427. http:// dx.doi.org/10.1007/s11262-008-0197-1

Singh L, Hallan V, Jabeen N, Singh AK, Ram R, Martin DP, Zaidi AA (2007): Coat protein gene diversity among Chrysanthemum virus B isolates from India. Arch. Virol. 152, 405-413. http://dx.doi.org/10.1007/s00705-006-0854-4

Singh L, Hallan V, Martin DP, Ram R, Zaidi AA (2012): Genomic sequence analysis of four new Chrysanthemum virus B isolates: evidence of RNA recombination. Arch. Virol. 157, 531-537. http://dx.doi.org/10.1007/s00705-011$\underline{1190-\mathrm{X}}$

Smith JM (1992): Analyzing the mosaic structure of genes. J. Mol. Evol. 34, 126-129. http://dx.doi.org/10.1007/ $\underline{\text { BF00182389 }}$

Takahashi T, Saito N, Goto M, Kawai A, Namba S, Yamashita S (1990): Apple stem grooving virus isolated from Japanese apricot (Prunus mume) imported from China. Res. Bull. Plant Prot. Ser. Jpn. 26,15-21.

Tamura K, Peterson D, Peterson N, Stecher G, Nei M, Kumar S (2011): MEGA5: molecular evolutionary genetics analysis using maximum likelihood, evolutionary distance, and maximum parsimony methods. Mol. Biol. Evol. 28, 2731-2739. http://dx.doi.org/10.1093/molbev/msr121

Tatineni S, Afunian MR, Gowda S, Hilf ME, Bar-Joseph M, Dawson WO (2009a): Characterization of the 5'-and 3'-terminal subgenomic RNAs produced by a capillovirus: Evidence for a CP subgenomic RNA. Virology 385, 521-528. http:// dx.doi.org/10.1016/j.virol.2008.12.024

Tatineni S, Afunian MR, Hilf ME, Gowda S, Dawson WO, Garnsey SM (2009b): Molecular characterization of Citrus tatter leaf virus historically associated with Meyer Lemon trees: complete genome sequence and development of biologically active in vitro transcripts. Phytopathology 99 , 423-431. http://dx.doi.org/10.1094/PHYTO-99-4-0423

Tugume AK, Mukasa SB, Kalkkinen N, Valkonen JPT (2010): Recombination and selection pressure in the ipomovirus Sweet potato mild mottle virus (Potyviridae) in wild species and cultivated sweetpotato in the centre of evolution in East Africa. J. Gen. Virol. 91, 1092-1108. http://dx.doi. org/10.1099/vir.0.016089-0 
Yanase H (1982): Back-transmission of Apple stem grooving virus to apple seedlings and induction of symptoms of apple topworking disease in Mitsuba kaido (Malus sieboldii) and Kobano zumi (Malus sieboldii var. arborescens) rootstocks. In: XII International Symposium on Fruit Tree Virus Diseases 130, pp. 117-122.
Yoshikawa N, Sasaki E, Kato M, Takahashi T (1992): The nucleotide sequence of apple stem grooving capillovirus genome. Virology 191, 98-105. http://dx.doi.org/10.1016/00426822(92)90170-T 